\title{
SPACE-PERCEPTION AND THE PHILOSOPHY OF SCIENCE
}





\title{
SPACE-PERCEPTION AND THE PHILOSOPHY OF SCIENCE
}

\author{
Patrick A. Heelan
}

UNIVERSITY OF CALIFORNIA PRESS

BERKELEY LOS ANGELES LONDON 
University of California Press

Berkeley and Los Angeles, California

University of California Press, Ltd.

London, England

Copyright (C) 1983 by The Regents of the University of California

Library of Congress Cataloging in Publication Data

Heelan, Patrick A.

Space-perception and the philosophy of science.

Bibliography: p. 353

Includes index.

1. Space perception. 2. Science-Philosophy.

I. Title.

BF469.H43

$121^{\prime} \cdot 3$

$82-4842$

ISBN 0-520-04611-0

AACR2

Printed in the United States of America

123456789 